\title{
Social Media and Its Use by the Government
}

\author{
Meetika Srivastava \\ Alumnus Department of Public Administration, University of Lucknow, \\ Lucknow, India \\ E-mail: meetikasrivastava22@gmail.com
}

Received: June 01, 2013 Accepted: June 16, 2013 DOI: 10.5296/jpag.v3i2.3978

\begin{abstract}
The present article aims to depict of how Information and Communication technology (ICT) is being used by governments to inform, engage and serve people. An attempt is made to study how the different governments worldwide are using the platform of social media in their governing models with special reference to the Indian government.
\end{abstract}

Keywords: Social media, Facebook, Twitter, Diplomacy, Digital Government 


\section{Introduction}

The 1990's technological revolution called the internet has truly transformed the world and its connectivity, from a few loosely connected millions now we are a thousand billion digitally connected world of networking people across borders and boundaries. People these days spend more time on their Laptops, smart phones and computers, whether to read newspapers online, to book travel ticket, listening to music, watching videos, for entertainment, to search information, buy any product through online shopping or engaging in public forums and discussions, reading e-books, e-journals, sharing pictures and videos and interacting with friends, family, business or government organizations via popular social networking sites like Facebook, Twitter, MySpace, YouTube, LinkedIn etc. All they need an internet connection and a computer. With the advent of Information and communications technology and the growing broadband penetration in urban, semi urban as well as rural areas has connected the masses like never before with a mere "click" of the mouse. Social media is the new medium through which individuals, businesses, organizations, government as well as civil society engages and interacts in this information age. Social networking sites like Facebook, Twitter, YouTube, etc can topple government regimes, boost political campaigns and contribute to presidential wins, bring about public protests, organize social demonstrations, mobilize social campaigns, and enable communications and discussions on public forum, spread awareness, provide instant news and information.

As the communications landscape gets denser, more complex, and more participatory, the networked population is gaining greater access to information, more opportunities to engage in public speech, and an enhanced ability to undertake collective action.

Social media have become a fact of life for civil society worldwide, involving many actors -regular citizens, activists, non-governmental organizations, telecommunications firms, software providers, governments. As social media increasingly becomes part of everyday life, more government agencies are carving out a social media presence online. Facebook, Twitter and YouTube not surprisingly, are perhaps the most common outlets for government social media efforts. Initially the governments worldwide were not that supportive of using social media for improving governance but slowly and steadily governments world over are embracing this platform.

In the 21st century, the government needs to more open and transparent about its working and these social networking sites can help in evolving a more participatory, innovative and inclusive governing model where the government not only spread awareness of its policies and plans but also engages in a two-way communication where they can get instant citizen feedback as well as incorporate suggestions made by common people for proper delivery of public services.

\section{What is Social Media?}

"Social Media is the biggest shift since the industrial revolution"

Eric Qualman, Socialnomics.

The revolution called social media has actually taken the world by storm and its growth has 
been exponential where Radio took 38 years to reach 50 million users, TV took 14 years to achieve the same target, and the internet got there in 4 years, iPod took 3 years for the same whereas Facebook added 100 million users in less than 9 months. Social networking has almost become the top most activity on the web. Every global brand has a social media presence; it is new marketing tool at their disposal and the hitherto not very supportive governments have also started using social media platform.

Social media includes web-based and mobile based technologies which are used to turn communication into interactive dialogue between organizations, communities, and individuals. Andreas Kaplan and Michael Haenlein define social media as "a group of Internet-based applications that build on the ideological and technological foundations of Web 2.0 and that allow the creation and exchange of user-generated content." Social media is ubiquitously accessible, and enabled by scalable communication techniques.

Social media is a way of describing easy ways to create, publish and engage on the internet. People generally use the term to describe how organisations and individuals share content text, video and pictures - and create conversations on the web. It is transforming the way that companies do business and individuals interact with each other. It is providing a voice for those who weren't well heard before. Social media will change the way that councillors and councils interact with local people.

The important thing to remember about social media is that it's social. It's about communication. It's about putting the transformative power of the printing press into the hands of the people. Just as the ability to publish political pamphlets and talk about them in coffee houses was the foundation of our liberal democracy, social media will have just as big an effect on the way we govern and do business. Now anyone can publish and share their views, and more importantly can engage in conversation with others about those views, with just a few clicks of a mouse. Social media is usually fairly open; meaning a wide variety of people can see, comment on or collaborate on materials. The tools are usually free or low-cost and very often easy-to-use, requiring no more skill than adding an attachment to an email or creating a Word document. And most importantly, social media is designed to be shareable, meaning that it's very easy for people to forward, link to or even re-publish content. This means there are very low barriers to entry for sharing opinions with a potentially very wide audience.

You may also see the term 'web 2.0'. This is used as shorthand to describe how social media has changed the content of the internet from being dominated by one-way publishing or e-commerce, to a greater emphasis on words, pictures, music and videos being published, shared and commented on by ordinary people.

Government 2.0 is sometimes used to describe how social media is changing the relationship between government institutions and citizens. Citizens and service users are increasingly expecting more open government and a greater say in how things happen in the place where they live and are probably already discussing your local issues online. Government 2.0 refers to open data to make government more transparent and accountable and the uses of social media tools to engage in those conversations, shape policy, support local democracy and 
improve services.

\section{Usage of social media by the governments worldwide}

\subsection{United States of America}

Politicians and governments agencies in the United States of America are extensively using the social media to interact and inform its citizenry. In America Social media use on the one side boosted President Barack Obama's grassroots presidential campaign (Facebook page http://www.facebook.com/barackobama and Twitter handle @BarackObama) in the year 2008 but on the other side former US Congressman Anthony Weiner's career collapsed after it was revealed he had sent lewd photographs and messages to at least six women online. An article on Washington Post revealed Barack Obama raised half a billion dollars online in his 21-month campaign for the White House, dramatically ushering in a new digital era in presidential fundraising.

Social networks like Twitter and Facebook have also been used in presidential debates and forums. The White House has even set up several verified Twitter accounts for state entities such as the secret service (@ $\underline{\text { SecretService)}}$, the Open Government Initiative (@ OpenGov), a Spanish White House account (@ lacasablanca) and an official account for White House Press Secretary Jay Carney (@presssec). Social media has become a place where politicians large and small can register their support in a public way, for example, when Hilary Clinton, Nancy Pelosi and Rep. Rosa DeLauro, D-Conn., called for the release of Chinese artist Ai Weiwei from police custody. Social media has also been used in national campaigns such as ChooseMyPlate.gov, for healthier eating,Serve.gov, for organizing and coordinating national volunteer efforts and for the White House blog.

Several government agencies are taking advantage of these Web 2.0 tools for recruiting and talent management, as well as improving job performance. For example, the CIA leverages Facebook as a method of attracting college students to apply for internships or jobs. The Environmental Protection Agency created a Facebook network for employees to achieve better talent management - as a way to share knowledge, build collaboration and improve employee engagement.

Other agencies are using public social networking Web sites as models for their own sites. NASA's CoLab program involved building its own collaborative workspace site to develop and support both online and offline groups and communities of practice.

The Environmental Protection Agency created a Facebook network for employees to achieve better talent management - as a way to share knowledge, build collaboration and improve employee engagement. https://www.facebook.com/EPA

You can access National Aeronautics and Space Administration - NASA's official Facebook page here https://www.facebook.com/NASA

NASA is extending a super-cool opportunity to 150 social media followers to chat live with International Space Station astronauts Kevin Ford, Tom Marshburn, and Chris Hadfield. http://venturebeat.com/2013/02/04/nasa-to-facebook-twitter-google-w... 


\subsection{United Kingdom (UK)}

In United Kingdom (UK), in October 2008 the Labour government set out their community empowerment agenda, proposing the use of social media by local government to engage communities: "We want to support innovation in the use of new technologies. This could be in the form of active debate and deliberative engagement with government or innovation in community and social media." (Department for Communities and Local Government, 2008)

In the last few years UK Councils have started to use blogs, Facebook, Twitter and YouTube to engage local communities. From deploying Yammer for policy and program support, to creative use of YouTube for recruitment, and through to using QR codes to create the world's first Wikipedia town, the UK's Monmouthshire County Council is a leading example of how local government can move beyond social tech to social communication for internal and external engagement. Helen Reynolds, Communications Officer for Monmouthshire County Council said in an interview "By being in social spaces where people are, and by being relevant and providing information that's timely and worth engaging with - that's how we build our influence as government."

According to guidelines issued by the U.K. government's digital service May 17, 2012

Civil servants in the United Kingdom should weave public engagement through social media into their daily work. "When civil servants, policy makers and service delivery units alike, open themselves to dialogue with the public they can glean a much better understanding of the real needs and concerns of citizens," writes Francis Maude, minister for cabinet office, in the document."Social media must be used responsibly and only when it enhances the core work of civil servants," he adds.

\subsection{Canada}

Most politicians in Canada are actively present on social media; some governmental departments are even taking steps to integrate social media into actually government operations. Glen Murray is the Minister of Research and Innovation for the province of Ontario. Following a social innovation summit, Murray wanted to find a way to bring the public into the discussion. Murray and two other ministries created a crowdsourced wiki to help create an official policy paper on what the government's approach to social innovation should be. Like Wikipedia, any user can add articles or edit submissions in a collaborative effort to create official policy.

gov.politwitter.ca is a companion tool to Politwitter that tracks social media activity by Canadian governments institutions \& organizations. Canadian Government Social Media

The world leaders of nations like, Brazil, Mexico, Venezuela, Argentina, United Arab Emirates and several others are exercising their influence on different social media platforms. Introducing the Most Popular World Leaders on Twitter

\subsection{Russia}

As part of the Russian government's drive towards modernization and increased use of technology, government ministries and agencies have put more effort into developing a 
presence online. In addition to official websites, many departments have established accounts in social networks and blogging communities. The purpose of this increased online outreach is not only to keep Russians informed about government actions, but also to receive feedback and comments from citizens.

All items on the agenda of the presidential commission are available for online discussion via the official website i-Russia.ru, where those interested in what is happening can post their comments via social networks such as Facebook, Twitter and VKontakte.

Five Mega-trends: How Social Media is Transforming Government http://www.businessesgrow.com/2011/04/04/five-mega-trends-how-socia...

\section{Indian government and social media}

The broadband penetration in India has increased and the number of mobile phone subscribers has also increased. India has the world's second-largest mobile phone user base with over 919 million users as of March 2012. It has the world's third-largest Internet users with over 121 million as of December 2011. In recent times India has become the world's most competitive and one of the fastest growing telecom markets.

Social media in India reaches out to 60 per cent of the online Indian audience. Facebook and Orkut, together cater to about 90 per cent of the users in the social media space. Facebook is the only social network in India that has witnessed a tremendous growth, almost doubling its users in the last 6 months. Social networking is what Indians spend most time on while online these days. According to the latest figures released by marketing research company ComScore, 84 percent of India's Internet audience visit social networking sites. This makes India the world's seventh largest market for social networking after U.S., China, Germany, Russian Federation, Brazil and the U.K.

The use of social networks has exploded globally and in India. LinkedIn gets around $33 \%$ of its revenue from outside the US. Facebook has 51 million users in the country and more than 900 million globally. Social networks now account for more than $25 \%$ of the overall time spent by users online globally, against an insignificant share in 2005, according to a November 2011 report by Avendus Capital.

At the 11th India Today Conclave, held on March 16 in New Delhi, the session on who will emerge victorious in the web wars, Facebook India head, Kirthiga Reddy opened her speech by laying emphasis on how web revolution depended on putting people at the centre, especially those based in rural areas. Stressing the importance of community initiatives, Reddy explained how through Facebook, farmers in Sangli, Maharashtra were able to reverse the price drop of turmeric. She further explained how tying up with government initiatives had the ability to bring about change in the society.

Rajan Anandan, country head, Google said at the conclave that Believe it or not, today 3.2 per cent of our GDP comes from the net and that number is only set to grow. The relevant question today is no longer one about who will win the web. Let's instead focus on getting the next million net users to $\log$ on.

The Government of India might be a slow adopter of the social medium but is certainly 
making up for it now. Prime Minister Manmohan Singh is on social networking site Facebook http://www.facebook.com/dr.manmohansingh that is frequently updated with political and personal updates. It has around 382,223 likes which shows the citizens are actually interested in engaging in political and policy discourses. The PMO maintains it and all information regarding important bills, legislations, PM statements, press releases, official visits, and photographs are regularly uploaded. PMO India has a twitter handle too http://twitter.com/pmoindia

It has several pages for the various programmes and policies of the government sharing progress and features of those policies:

National Rural Employment Guarantee Act https://www.facebook.com/nregs,

National Rural Health Mission https://www.facebook.com/nrhmindia.

Census Department also has Facebook presence http://www.facebook.com/Census2011 and its Twitter handle is @ IndiaCensus2011. In its initial run, the page mostly received questions around the enumeration process. Now, as the results begin to trickle in, the number of 'likes' has touched 31000 and the queries focus on the data -- on accessing it and on reading it. The office of the Registrar General of India, which conducts the Census, puts out release dates of new data sets and their highlights, with links to its website. It also invites comments. It's a two- way communication between the department and the people.

In an attempt to make planning process more participative as well as inclusive and to change its old image Planning commission debuted on Facebook as Twelfth Plan http://www.facebook.com/TwelfthPlan and also has a website. The Planning Commission aspires to reach out to people. It is the Commission's aim to involve all stakeholders in the process of planning and development. Everyone from industry associations, NGOs and common man can post suggestions on these platforms. The Commission has also started making extensive use of social media platforms like facebook, twitter, youtube, slide share flickr and google plus for this purpose https://www.facebook.com/PlanComIndia, The Planning Commission held its hackathon for the 12 Plan in April 2013. The hackathon which was held across the country from IIT Delhi to Aligarh Muslim University is part of the Planning Commission's aims to get more people involved in the 12th five-year Plan. The event, a first of its kind by any government body which involved students, youngsters, others in preparing infotainment, story boards, mobile apps, etc. Deputy Chairman of the Planning Commission, Mr. Montek Singh Ahluwalia said in a live interaction on Google Hangout on the occasion of the 63rd anniversary of the Commission that they would henceforth try and engage with youth of the nation as much as possible through these mediums. Planning Commission of India created an event on facebook12th Five Year Plan Hackathon. Its twitter account are also disseminating information and engaging with people @ $\underline{\text { PlanComIndia on }}$ Twitter.

Also there is a page on Facebook India@75 which is a grassroots and path breaking initiative of Confederation of Indian Industry (CII) which is a non-government, not-for-profit, industry led and industry managed organisation, playing a proactive role in India's development process. For realizing the dream of an inclusive, sustainable and developed India by the year 
2022, when India completes 75 years of Independence. It is a universal vision for India shared by Indians from all geographies and all walks of life.

Ministry of External Affairs and Public Diplomacy Division are optimally utilizing this social media. The key area of their focus is to develop effective Web 2.0 strategies and utilize a full range of social media tools that enable them to engage with diverse communities in India and overseas that have an interest in foreign policy issues. Official Facebook Page of the Ministry of External Affairs of India http://www.facebook.com/MEAINDIA, Official Facebook page/Twitter/YouTube channel of Public Diplomacy Division of Ministry of External Affairs, India are as follows www.indiandiplomacy.in, www.twitter.com/indiandiplomacy, www.youtube.com/indiandiplomacy.

Not many are untouched by the power of social media, but for the government to take a step towards a technology that opens new doors for communication, it's a welcoming change.

According to research firm Gartner, by 2012 Facebook, one of the most popular social media platforms will become the hub for social network integration and Web socialization. It is this type of simple adaptation of social networking which was the main objective of India's Public Diplomacy Division.

Launched in 2006 by the Ministry of External Affairs (MEA), the aim of the division was to spread awareness about India's foreign policy among its citizens. In 2010, the division became the first central government ministry to proactively use social media. A two-man army, Navdeep Suri, joint secretary and Abhay Kumar, under secretary, Public Diplomacy Division created a Facebook, Twitter, YouTube and Issuu account in July 2010. This was set up to encourage the youth to participate in government affairs and give their suggestions.

The Facebook page has been used for sharing photographs, videos and upcoming events while the Twitter account is used for engaging the young generation in brief conversations, political in nature. The YouTube account has been used for sharing short versions of documentaries produced by the Public Diplomacy Division. Issuu, on the other hand is used as an online publishing platform for releasing PHD magazines, India Perspectives and other guides and brochures.

The social media initiatives of the Public Diplomacy Division have served as a catalyst for many of our missions and posts abroad to start their own Facebook pages.

Former Foreign Secretary, Nirupama Rao, who is currently Ambassador of India to the United States of America, is the first senior Indian bureaucrat to join Twitter @NMenonRao. Rao has been a trailblazer in pushing the Ministry of External Affairs to adopt social networking tools. Her tweets especially during last year's Libyan evacuation are the highlight of her career. In one of her tweets amidst reports of protests being violently put down in Libya she posted on her twitter handle "Indians in Libya safe. Embassy in touch with Indians and Indian companies throughout Libya,"

As part of a public awareness campaign, the Ministry of information \& Broadcasting has set up a Facebook page (http://www.facebook.com/DigitalIndiaMIB), to address issues related to the process of digitalization, the deadline for which is 30th June 2012 for the 4 metros and 


\section{Macrothink}

31st December 2014 for the rest of the country. The Ministry has added some frequently asked questions and their answers related to digitalization under 'Notes', links to regulatory bodies and associations under Links, in addition to related pictures, and intends to interact with the public and other stake holders through the Wall at the Facebook page.

The Postal department of India was the first GOI department to go on asocial networking page and has resolved countless complaints and queries regarding posts through its twitter account @PostOfficeIndia http://twitter.com/postofficeindia . For a page that started out with trying to tell people about its activities such as commemorative stamps, exhibitions and its products, PostOfficeIndia has come quite far, says Radhika Doraiswamy, Secretary, Posts.

The Indian Government has decided to use Facebook, Twitter and other social media to reduce traffic accidents. The Facebook account of Delhi Traffic Police states in its official page's about section "we made substantial achievements in traffic management in 2010 and 2011. City had fewer accidents; drunken driving checks are having impact. Powerful people are also getting prosecuted. We intend to make things still better" and has 117,134 likes already.

The official accounts of UP Tourism on Facebook and Twitter (https://www.facebook.com/UttarPradeshTourismhttp://twitter.com/UP_IndiaTourism) are harnessing social media for showcasing the Tourist and heritage sites of Uttar Pradesh and in a way advertising and promoting tourism in UP, India.

At a time when the Prime Minister, Chief Ministers and even the Chief Election Commissioner are trying to connect to people through social networking sites, To help government organisations engage more fruitfully with stakeholders using the various social media platforms, Department of Information Technology (DIT) has drafted a document titled "Framework and Guidelines for Use of Social Media by Government Organisations".

\section{Conclusion}

Thus with the use of social media governments can be made more open, more transparent, more responsive and accountable for its act and can provide a quick, cost effective and two-way interactive platform for discussions and interactions of the governments with its local people, which will eventually help in better policy formulation and its effective implementation.

\section{References and web links}

1. How Governments are using social media for better \& for worse http://mashable.com/2011/07/25/government-social-media/

2. Terri Willard March 2009 Social Networking and Governance for Sustainable Development. http://www.iisd.org/pdf/2009/social_net_gov.pdf

3. Social Media Governance. http://socialmediagovernance.com/policies.php? $\mathrm{f}=5$

4. Using Social Media in Government http://www.howto.gov/social-media/using-social-media 
5. Just tweet to solve your postal problems http://www.hindustantimes.com/News-Feed/India/Just-tweet-to-solve-your-postal-pro blems/Article1-549512.aspx

6. Why does government social media use matter to citizens? http://gov20.govfresh.com/why-does-government-social-media-use-matter-to-citizens I

7. Tweet, Tweet, this is your PM and Ministry, folks! http://www.thehindubusinessline.com/industry-and-economy/marketing/article299176 2.ece

8. 10 Ways Facebook Pages Can Help Local Governments Better Serve Their Constituents http://www.insidefacebook.com/2009/11/05/10-ways-facebook-pages-can-help-localgovernments-better-serve-their-constituents/

9. US politics on Facebook http://www.facebook.com/uspolitics

10. Social Media Framework \& Guidelines for Government Organisations http://mit.gov.in/content/social-media-framework-guidelines-government-organisation $\underline{\mathrm{S}}$

11. Indian Government To Use Social Media To Clear Doubts Around Digitalization http://www.medianama.com/2012/03/223-indian-government-to-use-social-media-toclear-doubts-around-digitalization/

12. Indian Government into Social Media http://www.shoutmeloud.com/indian-government-into-social-media.html

13. Connected councillors -A guide to using social media to support local leadership http://www.idea.gov.uk/idk/aio/28632240

14. U.K. civil servants urged to use social media for policymaking, warned about security http://www.fiercegovernmentit.com/story/uk-civil-servants-urged-use-social-media-p olicymaking-warned-about-security/2012-05-30?utm_campaign=TwitterEditor-Fierce Government

15. Obama Raised Half a Billion Online http://voices.washingtonpost.com/44/2008/11/20/obama_raised_half_a_billion_on.ht $\underline{\mathrm{ml}}$

16. Social Media in India http://www.watconsult.com/2011/01/social-media-in-india-statistics-and-insights/

17. OSC Media Aid http://www.fas.org/irp/dni/osc/india-social.pdf

18. Indian Public Diplomacy Division http://www.indiandiplomacy.in/AboutUs.aspx

19. Social Media Empowers Youth to Participate in India's Foreign Affairs http://www.cio.in/article/social-media-empowers-youth-participate-india-s-foreign-aff $\underline{\text { airs }}$ 


\section{Macrothink}

Journal of Public Administration and Governance

20. Humbled to see $46 \mathrm{mn}$ Indians on Facebook

http://conclave.intoday.in/video/india-today-conclave-2012-kirthiga-reddy-rajan-anan dan/3380/38/67.html

21. Twitter, Facebook and YouTube's role in Arab Spring http://socialcapital.wordpress.com/2011/01/26/twitter-facebook-and-youtubes-role-intunisia-uprising/

22. Guidelines for govt. departments using networking sites http://www.thehindu.com/sci-tech/internet/article3284280.ece

23. An opportunity or a threat? How local government uses social media today http://www.guardian.co.uk/local-government-network/2012/feb/07/local-governmentsocial-media-today

24. Govt tells its MPs to use social media http://www.canberratimes.com.au/act-news/govt-tells-its-mps-to-use-social-me dia-20120525-1zaia.html

25. After the PM, chief election commissioner logs in to Twitter http://www.dnaindia.com/india/report_after-the-pm-chief-election-commissioner-logs -in-to-twitter 1656800

26. GovLoop http://www.facebook.com/govloop

27. Human Capital Institute January 2010 Social Networking in Government: Opportunities \& Challenges http://www.hci.org/files/field_content_file/SNGovt_SummaryFINAL.pdf

28. GovTwit is the world's largest directory of all facets of government on Twitter: state and local, federal, contractors, media, academics, non-profits and government outside of the U.S http://www.blog.govtwit.com/

29. When ROI = Return-On-Influence http://gov20radio.com/2012/05/return-on-influence/

30. Getting councillors out of the Town Hall and onto the Tweets http://twitter.com/\#!/TweetyHall

31. Socialnomics http://www.socialnomics.net/2009/08/11/statistics-show-social-media-is-bigger-than-y ou-think/

32. Arab Social Media Report http://www.dsg.ae/(X(1)A(kJhY52V2zQEkAAAAYWE4YjUwODYtNzQzNy00ZDZ iLTk1MTctOThiOTY2MmUzZDQ5edGyK13sjL6Y8MME04xURulUuLQ1))/en/asm r3/index.aspx?AspxAutoDetectCookieSupport=1

33. Social Media Revolution in India http://www.youtube.com/watch?v=wJsQegdSiZc

34. Social Media Revolution 2012 
http://www.youtube.com/watch?v=bveXo-BZrJQ\&feature=endscreen\&NR=1

35. Delhi Traffic Police Facebook page has over a lakh followers http://in.news.yahoo.com/delhi-traffic-police-facebook-page-over-lakh-followers-150 423324.html

36. http://www.business-standard.com/article/economy-policy/planning-commission-to-h old-32-hour-hackathon-in-april-113031500250_1.html

37. http://www.firstpost.com/india/planning-commissions-hackathon-good-start-but-what -next-693410.html

38. http://planningcommission.nic.in/hackathon/index.php

39. http://tech2.in.com/features/social-networking/indian-government-and-social-media/4 $\underline{74162}$

40. http://pib.nic.in/newsite/erelease.aspx?relid=82360

41. https://www.facebook.com/nregs 